\title{
The Problem of Subclass Features in Forensic Firearms Identification
}

Pavel Giverts' ${ }^{1}$, Andrey V. Kokin ${ }^{2,3}$

${ }^{1}$ Israel National Police H.Q., Jerusalem 91906, Israel

${ }^{2}$ The Russian Federal Centre of Forensic Science of the Ministry of Justice of the Russian Federation, Moscow 109028, Russia

${ }^{3}$ Kikot Moscow University of the Ministry of Internal Affairs of Russia, Moscow 117437, Russia

\begin{abstract}
The Russian school of forensic firearms investigation traditionally recognizes common and individual features of traces on bullets and cartridge cases. The first are characteristics inherent in all weapons of the same model and describing their details in general: shape, size, location, relative position. The second type are individual characteristics, which are unique and present only in one firearm. The individual features are used for forensic identification, while the common can be used only for the identification of a firearm's type and model.

The Western (West Europe and the USA) methodology of forensic ballistic identification recognizes the third type of traits - subclass characteristics. These marks are the result of manufacturing processes and can be present in a group of sequentially produced parts. Conventionally they can be placed between class and individual characteristics. One of the problems in contemporary firearms identification is the wrong recognition of subclass marks as individual marks and, as a result, giving false-positive conclusions of identification.

The article discusses the problem of subclass features, gives examples, presents a review of the literature. The influence of various technological processes on the possibility of showing up of these marks is described.
\end{abstract}

Keywords: firearm, traces, identification, common features, individual characteristics, subclass characteristics, forensic ballistics

For citation: Giverts P., Kokin A.V. The Problem of Subclass Features in Forensic Firearms Identification. Theory and Practice of Forensic Science. 2020. Vol. 15. No. 1. P. 109-117. https://doi.org/10.30764/1819-2785-2020-1-109-117

\section{Проблема подклассовых признаков в судебно-баллистической идентификации}

\section{D. Пиверц', (-) А.В. Кокин ${ }^{2,3}$}

${ }^{1}$ Штаб-квартира национальной полиции Израиля, Иерусалим 91906, Израиль

2 Федеральное бюджетное учреждение Российский федеральный центр судебной экспертизы при Министерстве юстиции Российской Федерации, Москва 109028, Россия

${ }^{3}$ ФГКОУ ВО «Московский университет Министерства внутренних дел Российской Федерации имени В.Я. Кикотя», Москва 117437, Россия

Аннотация. В российской школе судебно-баллистической идентификации в следах оружия на пулях и гильзах принято выделять общие и частные признаки. Первая группа - это признаки, присущие всем экземплярам оружия одной модели и характеризующие их детали в целом: форма, размеры, расположение, взаиморасположение. Вторая группа - это частные (индивидуальные) признаки, которые уникальны и проявляются только в одном экземпляре оружия. Частные признаки используются для криминалистической идентификации, в то время как общие признаки могут применяться только для определения типа и модели огнестрельного оружия.

В западной методологии (Европа и США) судебно-баллистической идентификации выделяется еще и третий тип признаков - подклассовые. Эти признаки являются результатом производственных процессов и могут быть представлены в их следах в группе последовательно изготовленных деталей. Условно их можно расположить между общими и частными признаками. Одной из проблем современной идентификации огнестрельного оружия является ложное восприятие подклассовых 
признаков как частных и, как результат, формулирование ошибочного положительного вывода о тождестве.

В статье рассмотрена проблема подклассовых признаков, приведены примеры и обзор литературы. Описано влияние различных технологических процессов на возможность проявления этого типа признаков.

Ключевые слова: огнестрельное оружие, следы, идентификация, общие признаки, частные признаки, подклассовые признаки, судебная баллистическая экспертиза

Для цитирования: Гиверц П., Кокин А.В. Проблема подклассовых признаков в судебно-баллистической идентификации // Теория и практика судебной экспертизы. 2020. Т. 15. № 1. С. 109-117. (Англ.). https://doi.org/10.30764/1819-2785-2020-1-109-117

\section{Introduction}

The forensic firearms identification and comparison of the marks on discharged cartridge cases and bullets build on scientific methodology. The scientific basis was developed in the 20-30es of the last century by an American forensic scientist Calvin Goddard. He investigated the manufacturing processes of firearms parts, marks produced by these parts on cartridge cases and bullets. At the same time, professor V. Balthazard, G.G. Williams, and others were also conducting similar researches. They applied the philosophic principle "nature never repeats" to the problem of forensic identification. As a result, they decided that the uniqueness and individuality of firearms' marks can be used for identification [1]. They even compared these marks to fingerprints [2].

On the cartridge cases and bullets, a great variety of different marks can be observed. At the beginning of the era of the forensic firearms investigation, these marks were divided into two main groups: the class or family characteristics and individual features.

The AFTE ${ }^{1}$ Glossary [3] gives the following definitions for these terms:

- Class Characteristics is "measurable features of a specimen which indicate a restricted group source. They result from design factors and are determined prior to manufacture."

- Individual Characteristics are "marks produced by the random imperfections or irregularities of tool surfaces. These random imperfections or irregularities are produced incidental to manufacture and/or caused by use, corrosion, or damage. They are unique to that tool to the practical exclusion of all other tools."

In other words, the individual characteristics are random, and due to this are unique. On the opposite, the class characteristics are the

${ }^{1}$ Assotiation of Fiream and Tool Mark Examiner. result of weapon design, such as shape and position of the firearms elements, and also the result of selected manufacturing technology, such as circular marks on the firing pin made by turning lathe.

Since the early period of developing forensic ballistic identification, one of the main questions has been, "is it possible that similar marks can be made by different firearms?" One of the first reported cases was discussed by Hatcher in 1935. He noticed the defect in a cutting tool, which had caused the appearance of a similar mark in multiple barrels, which were rifled by this tool [4]. More cases with marks like these were observed due to the development of forensic science and forensic firearms identification together with the rise in the number of examiners and evidence comparison. These marks can be carried over from one tool to a few consistently manufactured parts. They took place between class and individual characteristics. Burrard tried to use the term "family likeness" for this type of marks [5]. The term "subclass characteristics" is now used for them. Subclass characteristics are "features that may be produced during manufacture that are consistent among items fabricated by the same tool in the same approximate state of wear. These features are not determined prior to manufacture and are more restrictive than class characteristics" [3].

This means that the manufacturing process, which is made by the same tool, for example, the same broach or the same milling cutter, can make similar marks. It happens because different defects in cutting edges that come during its manufacturing, sharpening or using may leave similar marks in a few consistently manufactured parts. During the use of the tool, the shape of the cutting edge will change, and it will leave different marks.

The improvements in the methods of metal processing, the material used for metal cutting, 
and the new technology increased the possibility of subclass marks.

Since the subclass characteristics can cause mistakes during evidence comparison, they are recognized as one of the biggest problems in forensic firearms identification. This problem requires a more in-depth investigation. In Europe and the USA, dozens of articles and researches in this field have been published. In the former USSR countries, less attention has been paid to the problem of subclass marks. One of the aims of the article is to share the information concerning this problem with the community and explain the dangers of subclass characteristics in cartridge cases and bullets comparison. Also, the ways to decrease the possibility of making mistakes will be discussed.

\section{Subclass on cartridge cases}

In the process of comparison of cartridge cases marks made by different parts of firearms, are usually investigated those made by breech face, firing pin, ejector, extractor, chamber, and others. Each of these elements can be manufactured in different ways, using different methods and technological processes. The chosen way of processing influences the type of class characteristic and the possibility of subclass marks.

Breech face. Investigating a cartridge case discharge from FN HP-35 semiautomatic pistol, the breech face marks (Fig. 1) in the shape of a sequence of arches often can be

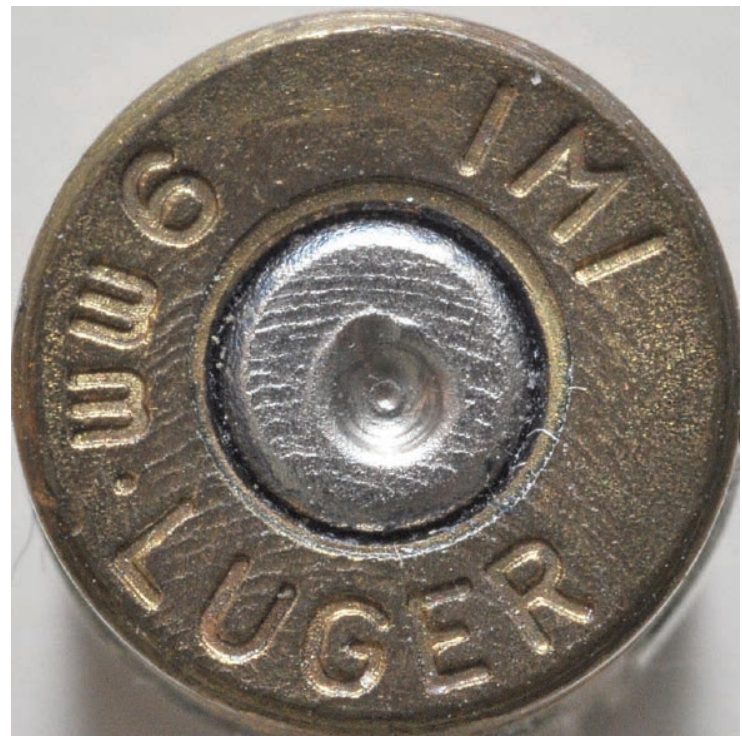

Fig. 1. Marks on the cartridge case dischardged from FN HP-35 pistol

Рис. 1. Следы на гильзе, стреляной в пистолете FN HP-35 observed. These arches are made during the milling process by the rotating mill tool. The arches are present in most breech faces of FN HP-35 pistols. So, they are the class characteristics and can be used only for the recognition of weapon type. The width and the depth of the arches, as well as the distances between them, are influenced by the shape of cutting edges of the mill, the velocity of rotation and movement of the tool, and other aspects. The combination of these parameters can be present on some weapons; therefore, they are subclass characteristics. Only the irregularities along the arches are unique and can be used as individual characteristics.

Another example of a subclass made by face milling process is the breech of Ruger M77 Mark II rifles (Fig. 2). Lopez and Grew [6] investigated six consecutively made bolts of this type of rifle and found that the striations produces by the mill tool repeat on all six of the investigated parts.

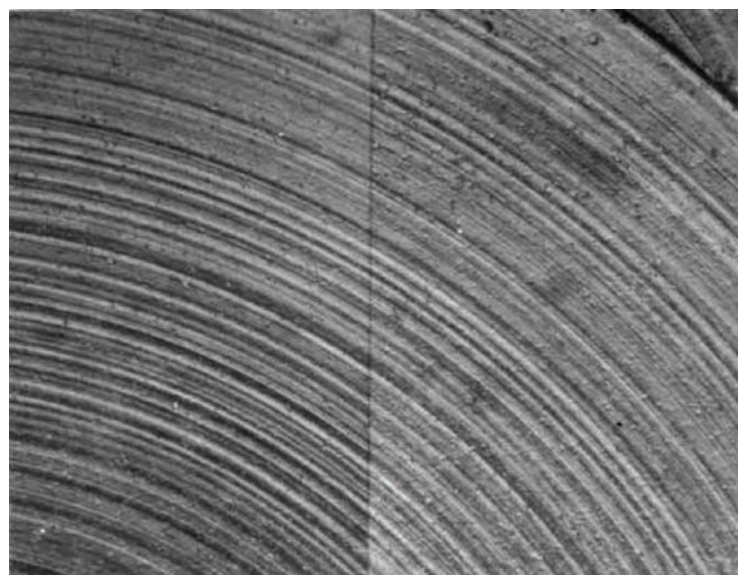

Fig. 2. Matching of surface microrelief of consecutively made breeches of Ruger M77 Mark II rifles (the left is the first and the right is the sixth) [6]

Рис. 2. Совмещение микрорельефа поверхностей патронных упоров последовательно изготовленных затворов карабинов Ruger M77 Mark II (слева первый затвор, справа - шестой) [6]

The use of CNC instead of manually operated machines can increase the possibility of observing subclass characteristics [7].

For weapons with other construction of breech can be used other manufacturing processes such as broaching (broach cutting), wire cutting, and others. In these types of process, the tool (the cutting edges of a broach or the cutting wire) leaves parallel marks which can be used for group identification, but not as individual marks since they can be subclass marks. Gene Rivera from North Carolina during routine casework investigated two Smith and 
Wesson SW40VE Sigma pistols with close serial numbers: PBV7152 and PBV7164 [8]. On the breech face of both pistols, very similar parallel marks were present (Fig. 3 and Fig. 4). According to the information that Rivera received from Smith and Wesson, the breech face area of these pistols was made by broach cutting: "This is a manual process in which an operator fixes a single slide into place as a broach is moved hydraulically across the breech face through the ejection port. The direction of the broach's movement was unknown. The broach is roughly four feet long with rectangular teeth that are approximately 5/8 of an inch apart. These teeth progressively cut deeper as they move along the working surface, while the last few teeth are for finishing and cleanup." After the broaching, the slides were heat-treated, tumbled, rough sandblasted, and finally, glass bead blasted. All these finishing processes were made to the whole slide and not specifically to the breech face area. Even though the slide passed a few operations that made random marks, like tumbling and sandblasting, the repeated subclass characteristics are still present and carry over to cartridge cases. Later, similar subclass characteristics were observed in another group of Smith and Wesson pistols, and that led to a more profound investigation of the manufacturing process of these pistols [9].

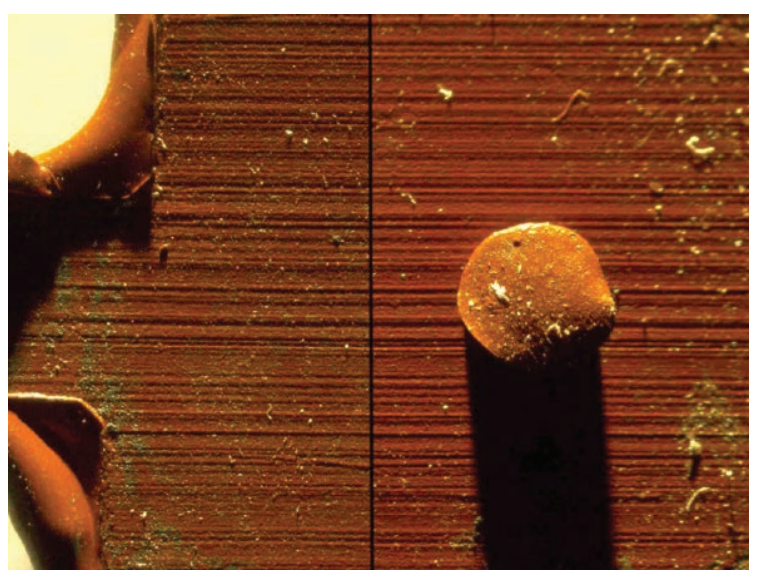

Fig. 3. Matching of the surface microrelief of breech faces of pistol PBV7152 (left) and pistol PBV7164 (right) [8]

Рис. 3. Совмещение микрорельефа на патронных упорах пистолетов PBV7152 (слева) и PBV7164 (справа) [8]

In the case of breech faces made by cutting processes, such as milling or broaching, the different irregularities in the marks of cutting tools (on the arches, rings, parallel lines) can be used as individual characteristics. Furthermore, the marks made by a sequence of opera-

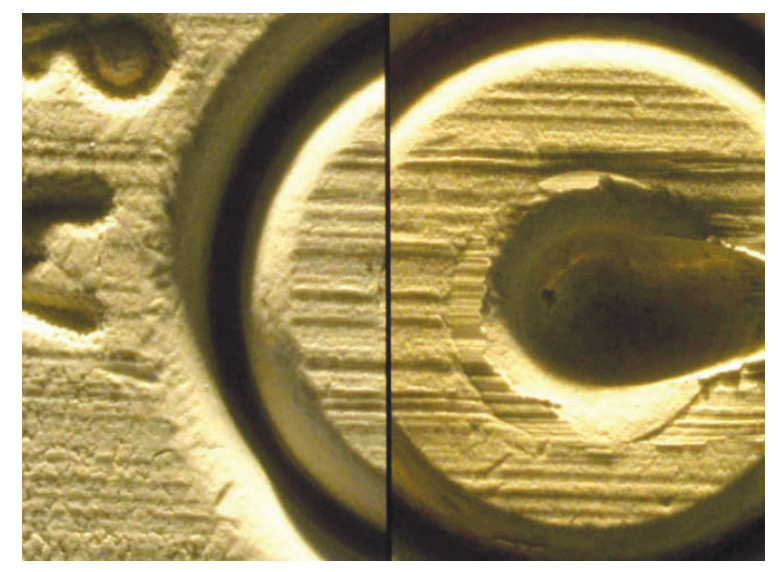

Fig. 4. Matching of the surface microrelief of cartridge cases dischardged from pistol PBV7152 (left) and pistol PBV7164 (right) [8]

Рис. 4. Совмещение микрорельефа следов патронного упора на гильзах, стрелянных из пистолетов PBV7152 (слева) и PBV7164 (справа) [8]

tions, for example, the combination of milling and broaching or slotting, can be accepted as individuals, even though each of them separately is possibly a subclass characteristic. The marks of random processes like tumbling or sandblasting are also individual.

For breeches, besides cutting processes, other methods, like molding and Metal Injection Molding (MIM), can be used. MIM is a comparatively new technology which is also used in firearms manufacturing ${ }^{2}[10-11]$. The parts consecutively made using this technology are a very close copy of one another. That is why the marks carryover to the cartridge cases may be similar. Moreover, while for cutting processes all irregularities are individual, in the parts made using MIM, they can also be subclass characteristics.

The big group of Tactical-Hulk PT-12 PRO pistols [12] had very similar marks with a combination of parallel lines and irregular shapes (Fig. 5). Moreover, the parallel lines on these marks had similar irregularities (Fig. 6). In the case of cutting manufacture, these irregularities can be taken as individual, but in the case of MIM or molding, they are subclass only. The same shape of subclass marks was also observed on converted Zoraki signal pistols [13].

Another example of irregular (random shape) subclass mark was observed in Jimenez JA Nine Pistol [14]. In these pistols, the slide is cast around the previously made bolt insert. During the molding, the metal bolt insert is fit-

${ }^{2}$ Metal injection molding. https://en.wikipedia.org/wiki/Metal_ injection_molding (date accessed: 10.08.2019). 


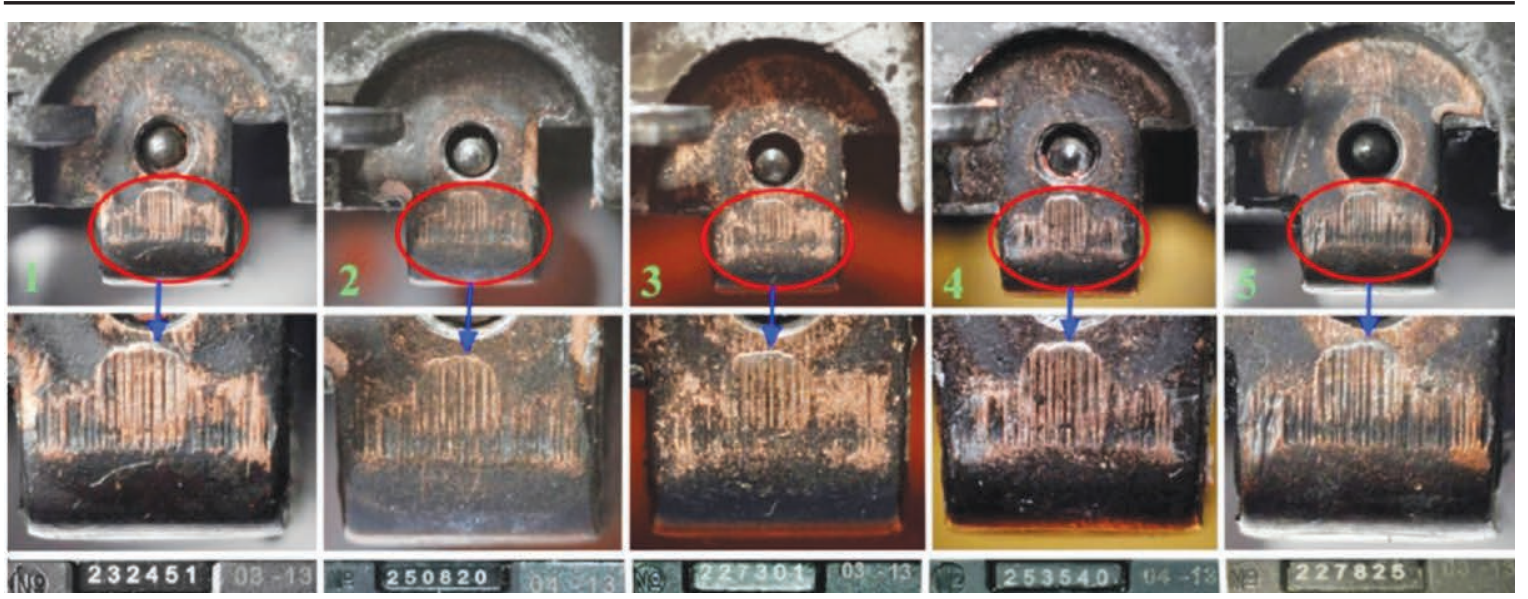

Fig. 5. Subclass marks on breech faces of five pistols Tactical Hulk PT-12 PRO [12]

Рис. 5. Подклассовые признаки в следах изготовления на патронных упорах пяти пистолетов Tactical Hulk PT-12 PRO [12]

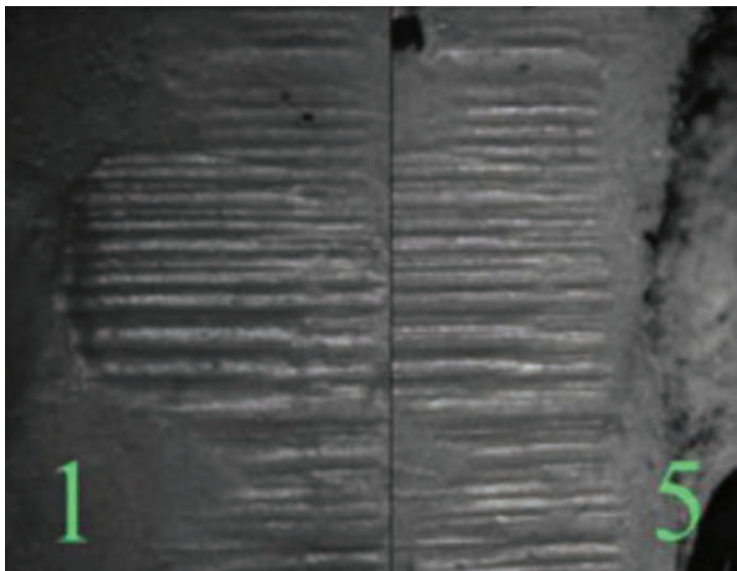

Fig. 6. Matching of subclass characteristics of two Tachtical Hulk PT-12 PRO pistols [12]

Рис. 6. Совмещение подклассовых признаков двух пистолетов Tactical Hulk PT-12 PRO [12]

ted tightly against a core piece in the mold. This operation can leave an impression on the part. From this part, the marks carry over to the cartridge cases (Fig. 7).

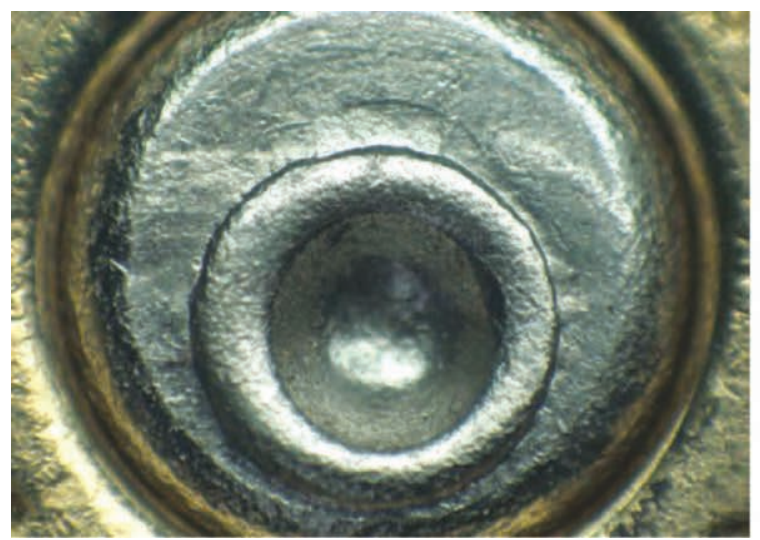

Firing pin. The firing pin is the part that hits the primer and causes cartridge discharge. In most firearms, the firing pin has a hemispherical front part. This part leaves firing pin impressions on cartridge cases. The subclass marks observed in firing pin impressions usually have the form of a set of circles. These circles on firing pins come as a result of the process of turning treatment. This type of subclass marks is simple to identify. In most cases, it is possible to find different irregularities in the circles, such as changes in the width of the mark, breaks in the circular marks, and others. These irregularities are individual and can be used for identification.

Due to the improvements and innovations in manufacturing processes, some manufacturers, such as Smith and Wesson, began to use the MIM technology instead of the turning treatment to manufacture firing pins. It was not surprising that similar repeating marks (subclass marks) were found on some firing pins produced using MIM [15]. Unlike the subclass marks made by turning treatments, those left

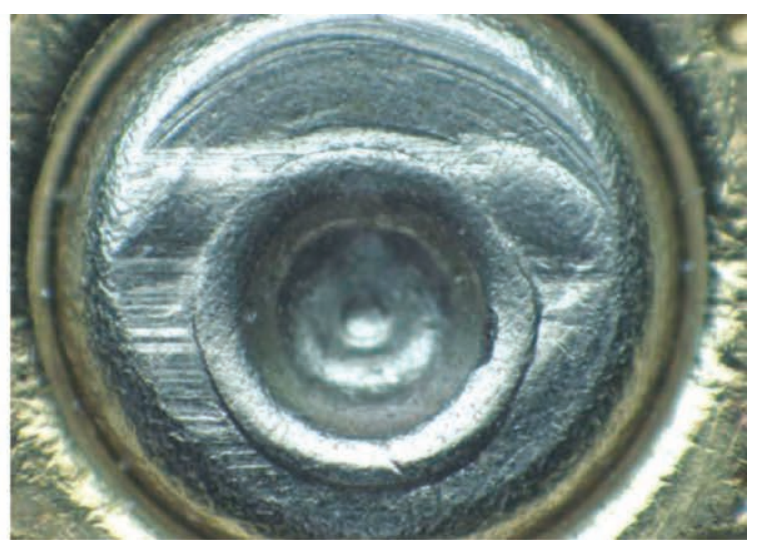

Fig. 7. Subclass marks on cartridge cases dischardged from two different Jimenez pistols [14]

Рис. 7. Подклассовые признаки в следах оружия на гильзах, стреляных в двух пистолетах Jimenez 
by MIM-made firing pins are laborious to identify. It is because MIM-made parts do not leave marks of regular geometrical forms (such as circles); these subclass marks may be of any shape (Fig. 8).

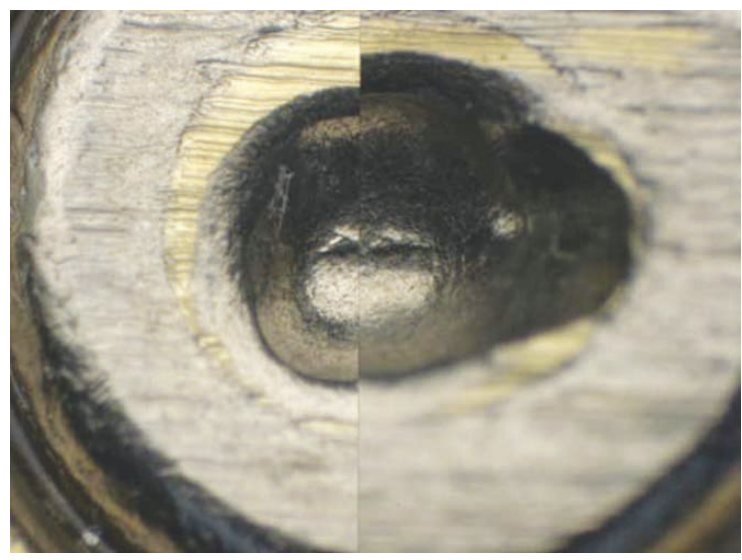

Fig. 8. Matching of firing pin marks for two $S \& W$ pistols [15]

Рис. 8. Сопоставление следов бойка двух пистолетов S \& W [15]

In the firearms designed for rimfire ammunition, such as 22 Long Rifle or 22 Remington Magnum, not only cylindrical firing pins are used. In most firearms, the firing pins have a rectangular front (hitting) area. As the turning treatment cannot be used for forming this type of firing pins, they are produced using other methods of metal cutting. Like every cutting method, this treatment can leave similar manufacturing marks on a sequentially made parts, so these marks are subclass [16]. In most cases, these firing pin manufacturing marks are a set of parallel lines that lets to recognize them as possible subclass (Fig. 9).

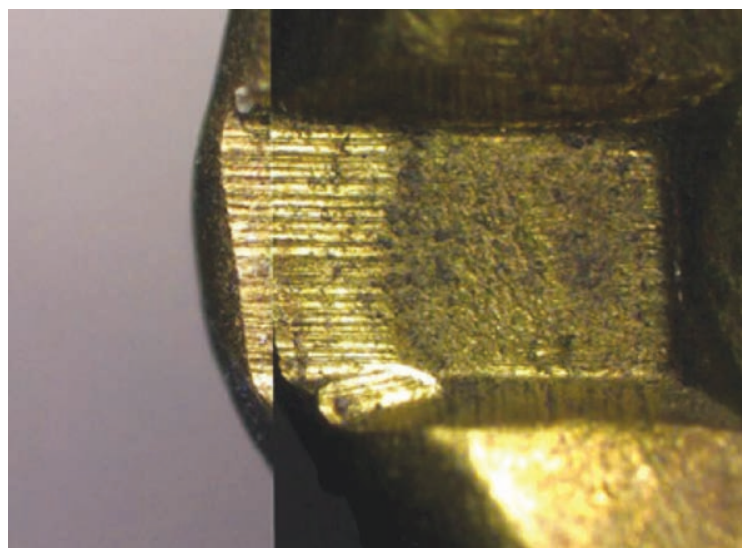

Fig. 9. Subclass marks left by firing pins of two Smith and Wesson M \& P 15-22 rifles [16]

Рис. 9. Подклассовые признаки в следах бойков двух карабинов Smith and Wesson M \& P 15-22 [16]
Other areas. Breech face and firing pin marks are the areas most used for comparison. Though, other areas of cartridge cases that were in contact with parts of the firearm during the discharge can also be used for comparison. In these areas, exactly like in a breech face and firing pins, the observed marks may be the subclass. Since these areas are not often used for comparison, they are less investigated in the aspect of subclass problem.

On the other hand, the principles of subclass recognition are the same and can be applied to the investigation of all mark types. The articles published in the professional and scientific literature give proof for this. For example, the subclass was observed in the comparison of anvil mark of Ruger MKII target pistols [17]. These marks are the result of the manufacturing of the rear part of the barrel used as an anvil for 22LR cartridges. The manufacturing marks repeat on a sequence of barrels and leave similar impressions on cartridge cases (Fig. 10).
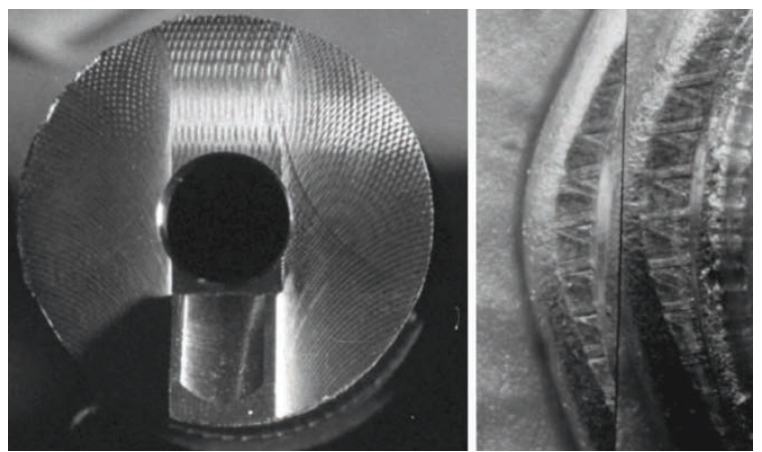

Fig. 10. The anvil (rear part of the barrel) of Ruger MKII pistol and the comparison of the marks made by two different anvils [17]

Рис. 10. Казенный срез ствола карабина Ruger MKII и сопоставление следов на гильзах, стреляных в двух разных карабинах [17]

\section{Subclass on bullets}

The main difference between the marks left by the firearms on bullets and the marks on cartridge cases is that the marks on bullets are striations and not impressions. These marks are the result of the bullet moving through the barrel. If the shape of the channel of the barrel in different cuts along the barrel is different, the striation on the bullets will be individual. However, if the marks along the barrel are the same, for example, the striation in the groove made during its cutting, which is the same along the barrel, it will leave marks on the bullet, which can be the subclass.

The question if the mark is individual or subclass can be answered by the investigation of 


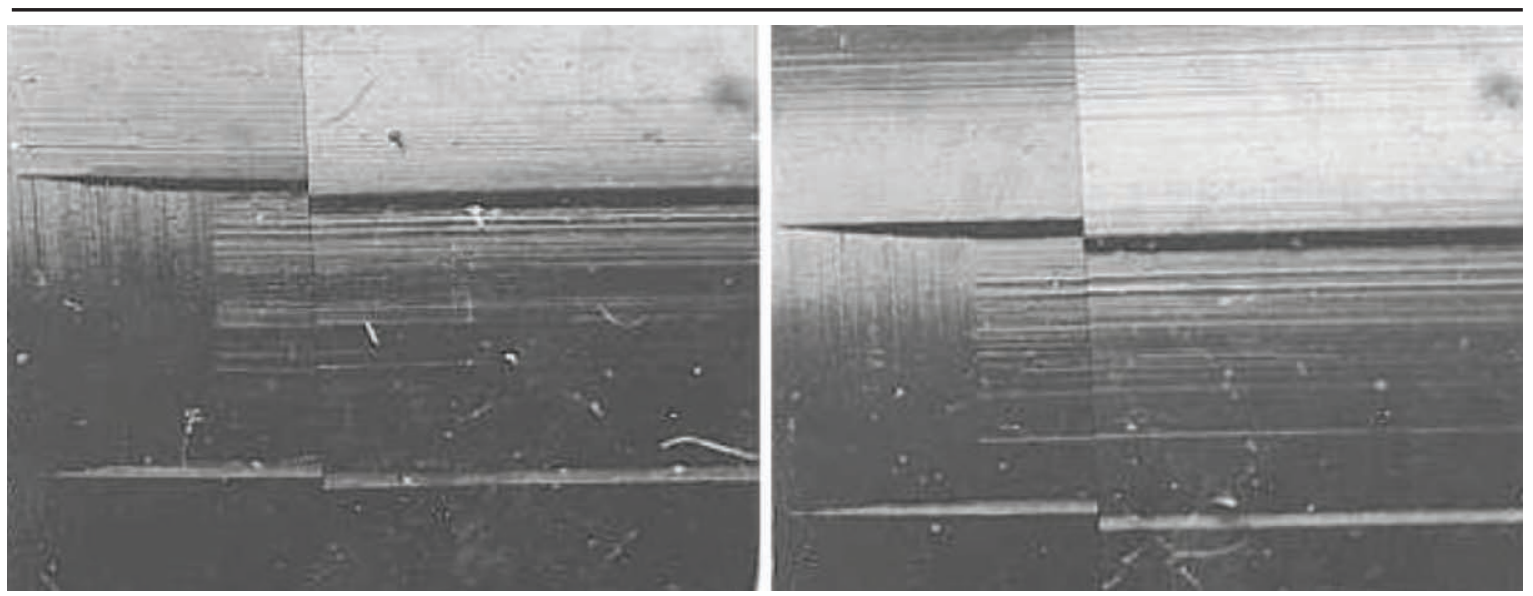

Fig. 11. Comparison of the marks on Mikrosil ${ }^{\mathrm{TM}}$ casts of lands of two consecutively rifled barrels [19] Рис. 11. Совмещение слепков (паста Mikrosil' ${ }^{\mathrm{M}}$ ) следов полей двух последовательно изготовленных стволов [19]

the manufacturing process used for making the barrel.

There are a few different ways of barrel manufacturing, such as hooking, broaching, buttoning, hammer forging, electrochemical etching, and others.

The standard operation for barrel rifling by hooking, broaching, and buttoning includes a few different steps. The first step is drilling. At this step, the barrel bore with the diameter of land-to-land (or smaller) is drilled. This process leaves along the barrel random circular striations. After the drilling, the honing process for polishing the internal surface can be applied. This process leaves on the internal surface of the barrel random marks only. The next step is the grooves formatting. In this process, the grooves can be made one by one (by hooking) or all grooves together (by broaching or buttoning). For groove to form, the tool is pushed or pulled through the bore. This movement is along the barrel, so the marks left by the tool can be parallel striations that go along the bore of the barrel. These marks can be repeated in a few sequentially manufactured barrels.

Analysis of the barrel manufacturing processes makes it possible to assume that the groove impression mark observed on the bullet can be subclass while the land impressions are individual. The first part of this assumption was proved when the subclass in the groove impression was observed [18]. The second part of the assumption has been refuted. The practice shows that some manufacturers use additional steps in the process of barrel making. Some of them use a special calibrating broach to calibrate bore diameter. This process leaves striations along the barrel bore; some of them are part of the land, and others are cut off during the groove format- ting. This type of marks was reported by Jerry Miller, who observed similar striation on the lands of two consecutively rifled barrels [19]. The corresponding marks were presented on Mikrosil $^{\mathrm{TM}}$ casts of land impressions, but their position to the edges of the land was different (Fig. 11). In recent years, some manufacturers have begun to use the tools (broach and button) where the calibration broach is part of the tool and makes the final treating. In barrels manufactured with this type of tools, the marks of land impressions can be the subclass, and their orientation to the land's edges can be similar.

Besides the discussed processes of rifled barrel manufacturing, other methods are used. One of these methods is a hammer forged method. In hammer forging, the internal surface of the barrel is formed by impressing the barrel material on special mandrel. If on the mandrel some defects are presented, they will be transferred to the internal surface of the barrel and leave marks on the bullet, which can be the subclass.

The possibility of subclass marks on bullets has been investigated and described in professional literature [20-23]. Some of these researches observed different subclass marks carried over to the bullets (Fig. 12). The examination of the bullets is becoming more complicated due to the problem of the possible subclass. Mr. O. Felix, during his presentation [24], asked the firearms examiners if they cast the barrel bore or use borescope for investigating the rifled surface of the barrel? In his opinion, it is the only way to eliminate the possibility of subclass marks on the examined bullets. In cases when the bore investigation discovers striations that are present along the bore these marks can- 
not be used for identification as they may be the subclass marks.

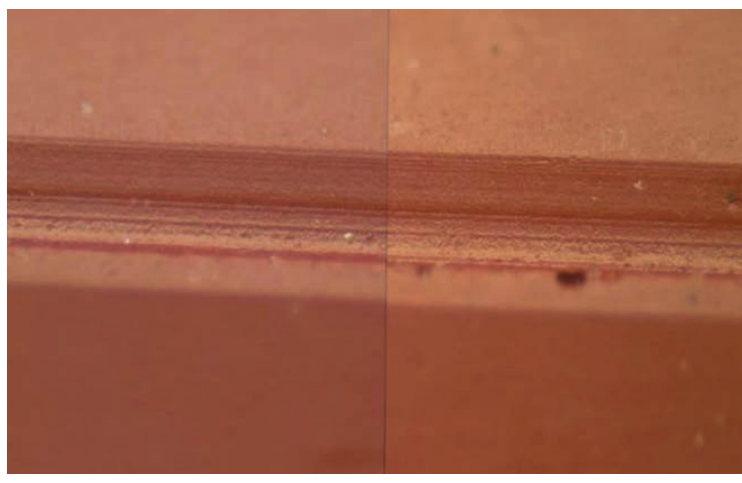

Fig. 12. Matching of subclass marks observed on rails of two Glock barrels [23]

Рис. 12. Совмещение подклассовых признаков в гранях двух стволов пистолетов Glock [23]

\section{Summary}

The possibility of subclass marks is one of the biggest problems in forensic firearms examination. The leading specialists, ballistic examiners, researchers around the world are

\section{REFERENCES / СПИСОК ЛИТЕРАТУРЫ}

1. Goddard C.H. Scientific Identification of Firearms and Bullets. The Journal of Criminal Law and Criminology. 1926. Vol. 17. Issue 2. P. 254-263. https://scholarlycommons. law. northwestern. edu/jclc/vol17/iss2/8/

2. Williams C.G. Fingerprints on bullets. Outdoor Life. 1922. Vol. 49. P. 329-331.

3. AFTE Glossary. $6^{\text {th }}$ ed. AFTE, 2017.

4. Hatcher J.S. Textbook of Firearms Investigation, Identification and Evidence. Plantersville. $2^{\text {nd }}$ ed. SC: Small Arms Technical Publishing Company, 1935. $904 \mathrm{p}$

5. Burrard G. The Identification of Firearms and Forensic Ballistics. London: Jenkins, 1934. $220 \mathrm{p}$.

6. Lopez L., Grew S. Consecutively Machined Ruger Bolt Faces. AFTE Journal. 2000. Vol. 32 No. 1. P. 19-24.

7. Coffman B.C. Computer Numerical Control (CNC) Production Tooling and Repeatable Characteristics on Ten Remington Model 870 Production Run Breech Bolts. AFTE Journal. 2003. Vol. 35. No. 1. P. 49-54.

8. Rivera G. Subclass Characteristics in Smith \& Wesson SW40VE Sigma Pistols. AFTE Journal. 2007. Vol. 39. No. 3. P. 253-259.

9. Lightstone L. The Potential for and Persistence of Subclass Chracteristics on the Breech Faces of SW40VE Smith \& Wesson Sigma Pistols. AFTE Journal. 2010. Vol. 42. No. 4. P. 308-322.

10. Kramer S. The Metal Injection Molding (MIM) Manufacturing Process. AFTE Journal. 2012. Vol. 44. No. 4. P. 367-368.

11. Nichols R. Metal Injection Molding - Manufacturing Review and Implications for Comparison and IBIS Performance. AFTE 50 ${ }^{\text {th }}$ Annual Train- investigating it. However, the school of firearms examination in former USSR countries and Russia has paid less attention to this problem in both practical and theoretical aspects.

The presented review shows that the problem is substantive for forensic identification. Ignoring or underestimating this problem may cause mistakes during cartridge cases and bullets comparison and result in false-positive conclusions in identification. The increasing reliability of forensic comparison and identification during firearms examination requires not only the knowledge of the problem. It also requires learning the methods and processes of firearms manufacturing, as well as their influence on the formation of marks and traces, which can be a carryover to the bullets or cartridge cases. Besides, it is essential to know how to recognize different types of marks (group, subclass, and individual). In cases where the observed marks may be the subclass, the examiner should be more conservative, making his conclusion about the identification.

ing Seminar: Nashville, TN, USA, May 26-31, 2019. P. 56.

12. Bar-Adon M., Bokobza L., Hazon A., Siso R. Subclass Characteristics Found on TacticalHulk Semi-Automatic Pistols. AFTE Journal. 2018. Vol. 50. No. 1. P. 38-42.

13. Pereira N. Known Non Matches - Zoraki M2906. Report 007 ENFSI EWG Firearms. 2015. https://epe.europol.europa.eu/documents/ 2632715/3100483/KNM007+-+Zoraki+M2906. pdf/3b46c971-fa2b-4356-b469-8ed48faa55a9 (date accessed: 10.08.2019).

14. Welch A.K. Breech Face Subclass Characteristics of the Jimenez JA Nine Pistol. AFTE Journal. 2013. Vol. 45. No. 4. P. 336-349.

15. Kramer S. Subclass Characteristics on Firing Pins Manufactured by «Metal Injection Molding». AFTE Journal. 2012. Vol. 44. No. 4. P. 364-366.

16. Lee M., Burritt M., Karsten R., Wickwire J., Jeffrey A. Subclass Carryover in Smith \& Wesson $M$ \& $P$ 15-22 Rifle Firing Pins. AFTE Journal. 2016. Vol. 48. No. 1. P. 27-32.

17. Nies R. Anvil Marks of the Ruger MKII Target Pistol - An Example of Subclass Characteristics. AFTE Journal. 2003. Vol. 35. No. 1. P. 75-78.

18. Tulleners F.A., Hamiel J. Sub Class Characteristics of Sequentially Rifled 38 Special S\&W Revolver Barrels. AFTE Journal. 1999. Vol. 31. No. 2. P. 117-122.

19. Miller J. An Examination of Two Consecutively Rifled Barrels and a Review of the Literature. AFTE Journal. 2000. Vol. 32. No. 3. P. 259-270.

20. Freeman R. Consecutively Rifled Polygon Barrels. AFTE Journal. 1978. Vol. 10. No. 2. P. 40-42.

21. Hall E. Bullet Markings from Consecutively Rifled Shilen DGA Barrels. AFTE Journal. 1983 Vol. 15. No. 1. P. 33-53. 
22. Mattijssen E.J.A.T., Kerkhoff W. Subclass Characteristics in a Gamo Air Rifle Barrel. AFTE Journal. 2013. Vol. 45. No. 3. P. 281-283.

23. Felix O., Palma J., Wharton T. Glock Marking Barrels - An Evaluation of Individual and Sub-

\section{ABOUT THE AUTHORS}

Giverts Pavel - Firearms Examiner in Division of Identification and Forensic Science, Israel Police, distinguished member of Association of Firearms and Toolmarks Examiners (AFTE), associated member of Firearms/GSR working group of European Network of Forensic Science Institutes (ENFSI);

e-mail: pavel.giverts@gmail.com

Kokin Andrey Vasil'evich - Doctor of Law, Master Forensic Examiner at the Laboratory of Toolmarks and Ballistics Examinations of the Russian Federal Centre of Forensic Science of the Russian Ministry of Justice, Professor of Department of Forensic Activities at Educational and Scientific Forensic Complex of Moscow University of the Ministry of Internal Affairs of the Russian Federation; e-mail: sbl@sudexpert.ru

Received: October 31, 2019 Revised: December 25, 2019 Accepted: January 15, 2020 class Characteristics. AFTE Journal. 2016 Vol. 48. No. 3. P. 169-172.

24. Felix O. Subclass Characteristics on Fired Bullets. AFTE $49^{\text {th }}$ Annual Training Seminar: Charleston, WV, USA, June 3-8, 2018. P. 34.

\section{ИНФОРМАЦИЯ ОБ АВТОРАХ}

Гиверц Павел - эксперт-баллист подразделения идентификации и судебной экспертизы полиции Израиля, почетный член Ассоциации экспертов огнестрельного оружия и трасологов (AFTE), член рабочей группы Firearms/GSR Европейской сети судебно-экспертных учреждений (ENFSI); e-mail: pavel.giverts@gmail.com

Кокин Андрей Васильевич - д. юр. н., главный государственный судебный эксперт лаборатории судебной трасологической и баллистической экспертизы ФБУ РФЦСЭ при Минюсте России, профессор кафедры экспертнокриминалистической деятельности учебнонаучного комплекса судебной экспертизы Московского университета МВД России имени В.Я. Кикотя; e-mail: sbl@sudexpert.ru

Статья поступила: 31.10.2019 После доработки: 25.12.2019 Принята к печати: 15.01.2020 